\title{
The Americanization of Ernst Moritz Arndt's Political Poetry in the Nineteenth Century
}

Written in 1813 as a response to the Wars of Liberation, Ernst Moritz Arndt's "Des Deutschen Vaterland" enjoyed an afterlife that few nineteenth-century patriotic poems could rival.' This literary phenomenon resulted in large part from the poem's focus on two central and recurrent issues in the German political landscape of the 1800 s - unification and hostilities with the French. Arndt begins his poem by suggesting a catalog of states and geographical regions as possible answers to the question posed in the first line, "Was ist des Teutschen Vaterland?": "Ist's Preußenland? Ist's Schwabenland? / Ist's, wo am Rhein die Rebe blüht? / Ist's, wo am Belt die Möwe zieht?"2 Repeatedly insisting that "Sein Vaterland muss größer seyn," the poet reveals his ultimate answer in the seventh stanza: "So weit die deutsche Zunge klingt / Und Gott im Himmel Lieder singt, / Das soll es seyn! / Das, wackrer Teutscher, nenne dein!" Arndt envisions a Germany that exists not only wherever German is spoken or sung, but also, as he states in the ninth stanza, "Wo Zorn vertilgt den welschen Tand./Wo jeder Franzmann heißet Feind,/Wo jeder Teutsche heißet Freund." Arndt himself recognized that his poem's visceral antiFrench rhetoric and call for a unified Germany helped explain its staying power. In a passage about a volunteer cavalry regiment in East Prussia preparing to fight against the French in 1813, he wrote:

Hier sprang jetzt aus dieser allgemeinen Begeisterung, die mit dem ganzen Volke in den Kampf gehen wollte, auch mein sogenanntes Deutsches Vaterlandslied hervor, das im lieben Deutschland noch in späteren Jahren gesungen ist und endlich wohl mit andern Tagesliedern zu seiner Zeit auch verklingen wird. Möchten wir in dem Augenblicke, worin wir eben leben, seinen Wünschen doch näher sein, als wir sind! ${ }^{3}$

${ }^{1}$ For an overview of the French occupation of the German states and the Wars of Liberation, see David Blackbourn: The Long Nineteenth Century: A History of Germany, 1780 1918. New York: Oxford University Press 1998. pp. 59-70, pp. 87-90; also Thomas Nipperdey: Deutsche Geschichte 1800-1866: Bürgerwelt und starker Staat, 4th ed. München: C. H. Beck 1987, pp. 11-101, in particular pp. 82-89.

2 Ernst Moritz Arndt: Katechismus für den Teutschen Kriegs- und Wehrmann. worin gelehret wird. wie ein christlicher Wehrmann seyn und mit Gott in den Streiten gehen soll. Köln: H. Rommerskirchen 1815. For the complete poem text and a history and analysis of the poem, see Sigrid Nieberle's essay '“Und Gott im Himmel Lieder singt': Zur prekären Rezeption von Ernst Moritz Arndts 'Des Deutschen Vaterland'” in this volume.

${ }^{3}$ Ernst Moritz Arndt: Meine Wanderungen und Wandelungen mit dem Reichsfreiherrn Heinrich Karl Friedrich vom Stein. edited by Robert Geerds. In: Ernst Moritz Arndts ausgewählte Werke in sechzehn Bänden, edited by Heinrich Meisner and Robert Geerds. Leipzig: Max Hesse 1908, vol. 8, p. 105. 
"Des Deutschen Vaterland," which appeared in German anthologies, the periodic press, and as sheet music or pamphlets, became a national anthem for large, organized groups of liberal, nationally-minded gymnasts, fraternity members, and singers for nearly four decades. They performed Arndt's song at their meetings and festivals, which served as important forums for political discussion prior to the Revolution of 1848 and thus enabled "Des Deutschen Vaterland" to play a role in the emergence of a German national consciousness in the first half of the nineteenth century. ${ }^{4}$ Not surprisingly, the poem resurged in popularity throughout the German states during the Franco-Prussian War of 1870-71, when a victory over the French enemy ensured the establishment of a German nation state. ${ }^{5}$

The afterlife of "Des Deutschen Vaterland," like that of many nineteenth-century patriotic poems, was also guaranteed by subsequent German poets who borrowed and imitated Arndt's verses, adapting his emotive language and imagery to comment on other historically significant moments. ${ }^{6}$ "Ein anderes 'Was ist des Deutschen Vaterland"'(1848), for example, ridicules German unification as a fiction: "Was ist des Deutschen Vaterland? / Wo man das Mährchen frech erfand: / Ein Acht-und-dreißiger-Verein/Könnt' einig, groß und mächtig sein?"7 The title of "Ein altes Lied" (1849) reveals a double meaning; while it alludes to Arndt's thirty-six-year-old poem, it also admonishes naïve Germans for allowing reactionary powers to regain a foothold after the failed Revolution of 1848: "Das ist des Deutschen Vaterland!/Jetzt, Deutsche, kennt Ihr Eure Schand!/So weit die deutsche Zunge lügt, / Betrog'nes Volk sich selbst betrügt." ${ }^{8}$ In contrast, Ferdinand Freiligrath quotes Arndt in the fifth stanza of "Hurrah, Germania!" (1870) to express his elation over the imminent unification of Germany: "Was ist des Deutschen Vaterland, -/Wir fragen's heut nicht mehr! /Ein Geist, Ein Arm, Ein einz'ger Leib, / Ein Wille sind wir heut!"9

The nineteenth century witnessed German mass migration to the United States, suggesting that "Des Deutschen Vaterland" may have experienced an afterlife in

${ }^{4}$ Dieter Düding: Organisierter gesellschaftlicher Nationalismus in Deutschland (18081847): Bedeutung und Funktion der Turner- und Sängervereine für die deutsche Nationalbewegung. München: R. Oldenbourg 1984, p. 271.

5 For a historical account of the Franco-Prussian War, see Blackbourn: The Long Nineteenth Century: A History of Germany, 1780-1918 (footnote 1), pp. 243-59; Thomas Nipperdey: Deutsche Geschichte 1866-1918, $3^{\text {rd }}$ ed. Vol. 2, Machtstaat vor der Demokratie. München: C. H. Beck 1995, pp. 11-84.

6 Other German patriotic poems that resurfaced in this manner include Nikolaus Becker's "Der deutsche Rhein" (1840), Max Schneckenburger's "Die Wacht am Rhein" (1840, see footnote 26 below), August Heinrich Hoffmann von Fallersleben's "Das Lied der Deutschen” (1841), and Matthäus Chemnitz's “An Schleswig-Holstein” (1844). See Lorie A. Vanchena: Political Poetry in Periodicals and the Shaping of German National Consciousness in Nineteenth-Century Germany. (North American Studies in $19^{\text {th }}$-Century German Literature 26) New York: Peter Lang 2000. The accompanying CD-ROM presents an anthology of 950 political poems and several searchable indices.

7 Vanchena, CD-ROM, poem 287 (footnote 6).

8 Vanchena, CD-ROM, poem 458 (footnote 6).

9 Vanchena, CD-ROM, poem 856 (footnote 6). 
the New World, too. As we shall see, German immigrants did transfer Arndt's poem to their new national landscape, adapting it to social-political circumstances that were at once American, German, and German-American in nature. American publications that featured "Des Deutschen Vaterland" - in particular a broadsheet and three pieces of sheet music from 1870 , and a poetry anthology from 1883 - as well as the cultural contexts in which the poem was published or performed, offer insight as to how and why Arndt's popular text was appropriated by Germans living in the United States. This paper seeks to demonstrate that immigrants' use of Arndt's patriotic verses exemplifies the process of "Americanization", defined by Lynne Tatlock and Matt Erlin as "the creative adaptation in local, regional and national settings in the United States of cultural material that emanated from the German-speaking territories in Europe." 10 In taking up Arndt's verses, GermanAmericans often adapted the poem to their new home by translating it into English; their appropriation of "Des Deutschen Vaterland" therefore sheds light not only on the process of acculturation but also on the role played by Americans and their culture in the development of a hybrid, German-American identity. As historian Kathleen Neils Conzen has observed, German immigrants could not lead an isolated existence within the American landscape, even though many of them had originally envisioned their new country as an unpopulated, undeveloped space in which they could create an ideal Germany. ${ }^{11}$ They developed strategies, however, that enabled them to respond to and even shape the social-political culture of the United States. The appropriation of Arndt's German cultural material is also significant within the framework of an international collaborative effort currently focused on reimagining the German-American tradition as part of multi-ethnic America. ${ }^{12}$

"Des Deutschen Vaterland" appeared in at least four American publications in 1870 , a year that represented a significant juncture not only in German but also in German-American history. A wave of German migration to the New World had peaked from 1866 to 1869 , a result of increased German conscription during the wars against Denmark in 1864 and Austria in 1866 and, on the North American side of the Atlantic, the Homestead Act of 1862 (which gave settlers up to 160 acres if they lived on the land for at least five years) and the expansion of American

${ }^{10}$ Lynne Tatlock and Matt Erlin: Introduction. In: L. T. and M. E. (eds.): German Culture in Nineteenth-Century America: Reception, Adaptation, Transformation. (Studies in German Literature, Linguistics, and Culture) Rochester, NY: Camden House 2005, p. xi.

11 Kathleen Neils Conzen: Phantom Landscapes of Colonization: Germans in the Making of a Pluralist America. In: Frank Trommler and Elliott Shore (eds.): The German-American Encounter: Conflict and Cooperation between Two Cultures 1800-2000. New York: Berghahn Books 2001, pp. 7-21.

12 Werner Sollors: Series Editor's Foreword:The German-American Tradition Reconsidered. In: Reinhold Solger: Anton in America: A Novel from German-American Life. Translated and introduced by Lorie A. Vanchena. (New Directions in German-American Studies 3) New York: Peter Lang (2006), pp.xviii-vi. See also Winfried Fluck and Werner Sollors (eds.): German? American? Literature? New Directions in German-American Studies. (New Directions in German-American Studies 2) New York: Peter Lang 2002. 
industry after the Civil War. ${ }^{13}$ The German population of New York City expanded from 200,000 in 1860 to 370,000 in 1880 , when it constituted approximately one third of the city's population. ${ }^{14}$ The Franco-Prussian conflict resonated among German immigrants living in the United States, as evidenced by their extensive efforts during the summer and fall of 1870 to organize mass meetings, patriotic aid societies, volunteer corps, and fundraising events in support of the German war effort. ${ }^{15}$ The German-language press in the United States also embraced Bismarck's war against France; journalists' enthusiasm for a unified Germany outweighed their earlier, more liberal concerns about the suppression of civil rights and the expansion of Prussian power. ${ }^{16}$ Furthermore, the issue of national unity undoubtedly struck a chord among many German-Americans because of recent American history. The Civil War, fought to save the Union from being torn apart over the issue of slavery, had ended just five years earlier; the causes espoused by the Northern states and the Republican Party had found staunch supporters among Germans who had emigrated to the United States seeking opportunity for political expression and engagement that had not existed under absolutist rule in the German states. ${ }^{17}$

Let us now turn to the first publication featuring Arndt's poem, a broadsheet entitled What is the German's Fatherland? ${ }^{18}$ "Translated from the German of Arndt" by Theodor Sutro, a young Prussian-born immigrant who was studying at Harvard University, the English text includes all ten stanzas of the original poem. ${ }^{19}$ A line of text beneath Sutro's name indicates that the broadsheet was printed in conjunction with a "German Verbruederungs-Fest, New York, August 19,1870," an event covered in three different issues of the New-York Tribune. (The combination of English and German seen here will also be found in the German-American publications discussed below.) A daily newspaper, the New-York Tribune regularly printed accounts not only of the Franco-Prussian War but also of German-American

13 La Vern J. Rippley: The German-Americans. Lanham, MD: University of America Press 1984 (reprint, 1976), pp.72-84. German immigration first crested in 1854; it reached its highest point in the mid-1880s.

14 New York City would serve as the country's major German-American center until the early twentieth century. See Stanley Nadel: Germans. In: Kenneth T. Jackson (ed.): The Encyclopedia of New York City. New Haven: Yale University Press 1995, pp. 463-64.

15 See footnote 20 below.

16 Rippley: The German-Americans (footnote 13), p. 164.

17 See James M. Bergquist: The Forty-Eighters: Catalysts of German-American Politics. In: Trommler and Shore: The German-American Encounter (footnote 11), pp. 22-36.

18 Ernst Moritz Arndt:What is the German's Fatherland? Translated by Theodore Sutro. New York: John Sarell 1870.

19 Sutro would graduate from Harvard in 1871 and then earn a law degree from Columbia University. In the early twentieth century, Sutro served as president of the DeutschAmerikanischer Staats-Verband and played an active role in many other German cultural and political organizations; he was considered New York's "most prominent and publicspirited German-American citizen." In: Resolution Favoring Theodore Sutro for United States Senator and Biographical Sketch. New York: Deutsch-Amerikanischer StaatsVerband 1911, p.6. 
(and French-American) wartime activities in New York. ${ }^{20}$ The Verbruederungs-Fest was first announced on August 10, in the "Local War News" section of the paper; a "United German Fraternal Festival," the article stated, was to be held on August 19 "for the benefit of the wounded, widows, and orphans of the war in Europe." 21 The evening's entertainment would include a prologue, songs by the different singing societies of New York, Schiller's Wallenstein's Lager (note once more the combination of German and English) "by the principal performers of the Stadt Theater and singing societies of New-York," orations, a picnic, and fireworks. ${ }^{22}$

One week later, on August 17, the New-York Tribune published a second article, again in the "Local War News" section. This time the event was called "The Great Demonstration at Jones's Wood" - a title that underscored the political nature of the fundraising celebration. ${ }^{23} \mathrm{~A}$ large park in uptown Manhattan, Jones's Wood was a popular pleasure ground used by private clubs, church groups, benevolent societies, and labor unions for outings, sporting events, social gatherings, and festivals; the location was especially favored by the city's German population. ${ }^{24}$ According to the article, “Over 9,000 tickets have been distributed for the great festival at Jones's Wood on Friday, and the Committee expects to dispose of as many more before that day." Invited guests included the Consul of the North German Confederation, Mayor Hall of New York City, General Franz Sigel, and "other well-known citizens." 25 The Committee planned "to issue a circular inviting all German proprietors of public houses, as well as all business men of that nationality, to close stores on Friday, that themselves and employés [sic] may take part in the festivities." The program, now presented in greater detail, would highlight festive music by German composers, including Carl Maria von Weber's Jubilee Overture (1818); Giacomo

20 The New-York Tribune (1844-1966) was founded by Horace Greeley (1811-72). By the 1850 s it had become the most influential Republican newspaper in the country, with a circulation of more than 200,000. Steven H. Jaffe: New York Tribune. In: Jackson: Encyclopedia of New York City (footnote 14), p. 848. On August 5, 1870, for example, the newspaper published a map showing the position of French and German troops, numerous reports from the theater of war, and meeting notices for the French Patriotic Aid Society, the Executive Committee of the German Patriotic Aid Society, the German Veterans of War of the Rebellion, and the German-American Free Corps.

21 "German Aid Festival", New-York Tribune, August 10, 1870. The "Committee of Management" for the United German Fraternal Festival included General Samuel P. Heintzelman (1805-80), a brigadier general for the Union Army during the Civil War; the president of the New York Männerchor; the director of the Germania Bank; and other prominent German-Americans.

22 Friedrich von Schiller's Wallensteins Lager, the first drama in his trilogy Wallenstein: Ein dramatisches Gedicht (1800), premiered in 1798.

2.3 "The Great Demonstration at Jones's Wood," New-York Tribune, August 17, 1870.

24 Joy M. Kestenbaum: Jones's Wood. In: Jackson: Encyclopedia of New York City (footnote 14), p. 626 .

25 A. Oakey Hall (1826-98) served as mayor of New York City 1868-72. Forty-eighter Franz Sigel (1824-1902), a major-general in the Union Army during the Civil War, later worked as an editor and public official in New York. Jerome Mushkat: A(braham) Oakey Hall. In: Ibid., p. 517; in the same volume, see Stephen D. Engle's entry on Franz Sigel, p. 1069. 
Meyerbeer's "Crown March of the People" ("Coronation March") from his opera Le Prophète (1841); and a performance by "Various Singing Societies" of Max Schneckenburger's immensely popular "Die Wacht am Rhein" (1840). ${ }^{26}$ The first two pieces may have been included on the program as much for their political significance as for their celebratory nature. Weber, at the end of his Jubel-Ouvertiure, integrates his orchestration of "God Save the King" from Kampf und Sieg (1815), a cantata he composed in response to Napoleon's defeat at the Battle of Waterloo.27 Meyerbeer's Le Prophète became unexpectedly relevant when it premiered in Paris in 1849, just one year after the revolutions of 1848 ; many drew parallels between the Anabaptist revolt depicted in the opera and the ill-fated insurgency led by Parisian students and workers in June 1848 that signaled the start of the counterrevolution. ${ }^{28}$ The program for the "Great Demonstration" would also include an "inaugural address" by Dr. Herzberg, the president of the General Aid Society (and presumably a German-American), followed by Arndt's "Was ist des Deutschen Vaterland?" - a "Grand Chorus, by Assembly, with Orchestral accompaniment." After this audience-participation number, the previously announced "Wallenstein's Camp, from Schiller" would be performed, and the evening would conclude with "Dancing, Fireworks, etc."

The New-York Tribune reported on the German-American festival on August 20; "German Pic-Nic [sic] at Jones's Wood" appeared beneath the heading "Movements of the Germans" in the "Local War News" section. ${ }^{29}$ Although the expected crowd of 18,000 had not materialized, the evening was hailed as a success:

Two or three thousand German citizens [...] held a pic-nic yesterday at Jones's Wood, the proceeds of which are to be devoted to the German Patriotic Fund. The grounds were decorated with flags, and the dancing Hall had a very gay appearance, and at night was illuminated with Chinese lanterns. The entertainment opened with the Jubel overture, played by Eben's Band. Gen. Heintzleman [sic] then introduced Dr. Herzberg, who made an eloquent address, chiefly congratulating the Germans upon the unification of the several principalities of the Fatherland. He said a despotic form of Government for Germany was impossible, and that free Germans must be united Germans. 'These three nations America, England and Germany - are the three powers of the modern world that represent national freedom in contradistinction to French Caesarism.'

26 Schneckenburger (1809-49) wrote his "Rheinlied" in response to France's threat to reclaim the left bank of the Rhine; the specter of war generated intense patriotic, anti-French sentiment. The New-York Tribune published an English translation of the poem, "The Guard on the Rhine," on August 17. See Vanchena: Political Poetry in Periodicals and the Shaping of German National Consciousness in Nineteenth-Century Germany (footnote 6), pp. 176-83; also Vanchena: The Rhine Crisis of 1840: Rheinlieder, German Nationalism, and the Masses. In: Nicholas Vazsonyi (ed.): Searching for Common Ground: Diskurse zur deutschen Identität 1750-1871. Köln: Böhlau Verlag, 2000, pp. 239-251.

27 Carl Maria von Weber (1786-1826), a composer, conductor, and pianist, is regarded as the founder of the German romantic school of opera.

28 Meyerbeer, born Jakob Liebmann Meyer (1791-1864), was the most frequently performed German opera composer during the nineteenth century. Steven Huebner: Giacomo Meyerbeer. In: Stanley Sadie (ed.): The New Grove Dictionary of Opera, 4 vols. Oxford: Oxford University Press 1992, vol. 3, pp. 366-71, here pp. 367-68.

29 “German Pic-Nic at Jones's Wood”, New-York Tribune, August 20, 1870. 
A "prologue in verse, spoken by Fräulein Rhode," which focused on the recent German victories, followed Herzberg's speech; the "dancing and other amusements," the report concluded, continued until the early hours of the morning. ${ }^{30}$ In his address, Herzberg also mentioned recent German history - Prussia's consolidation of power in northern Germany and the creation of a North German Confederation in 1867 - as well as current events; his call for a unified country with a government that ensured the civil rights of its citizens is a reference to the Franco-Prussian War. He also alluded to American events (not only the Civil War but the American Revolution, fought to liberate the colonies from British rule), thus drawing parallels between German and American history. The report published in the New-York Tribune, although it does not discuss the evening in great detail, thus sheds light on the German, American, and German-American aspects of the celebration.

Conclusions as to the purpose of Sutro's broadsheet must remain speculative at this point. Perhaps it was distributed for publicity purposes prior to the celebration at Jones's Wood, as its title, "German Verbruederungs-Fest," resembles the earliest announcement published in the New-York Tribune; perhaps it was handed out to those attending the celebration so that non-German speakers would have the opportunity to sing along with the audience. The original German text may have been provided, too, although the program organizers probably could have expected many of those in attendance to know the original German verses. Finally, the broadsheet may have been published after the "Great Demonstration," as a souvenir to mark the occasion. Sutro's English transformation remains fairly close to the original German text: "What is the German's Fatherland? / Is't Prussia? Is't Suabian land? / Is't on the Rhine, the grape-vine's home? / Is't on the Belt, where sea-gulls roam? / Ah! No! No! No!/His Fatherland must greater be!" His rendering of Arndt's answer to the initial question reads: "What is the German's Fatherland? / Then name at last that mighty land!/ Where e'er the German tongue may ring, / And hymns to God on High doth sing, / That shall it be! that shall it be! / That valiant German claim for thee!" The "German's Fatherland" is also "Where hate spurns France's foul demand, / Where all the wicked, foes are deemed, / Where good alone, friends are esteemed." As we shall see, Sutro's publication is the only one discussed in this essay that includes these anti-French lines as well as the sixth stanza (the so-called Fürstenstrophe), which alludes to conflicts over German borders and territory. ${ }^{31}$

A second example of the Americanization of Arndt's poem, a piece of sheet music also published in New York City in 1870, features "Des Deutschen Vaterland" along with Schneckenburger's "Die Wacht am Rhein." 32 The Rhine served as a

${ }^{30}$ Fräulein Rhode could not be identified.

31 According to Nieberle, a shortened version of "Des Deutschen Vaterland" that included Arndt's first five stanzas and the seventh, published in 1832 with a melody composed by Gustav Reichardt (1797-1844), became the most popular version of the poem. Nieberle (footnote 2).

32 Watch on the Rhine and What is the German's Fatherland?: Two German National Songs. (Musical Bouquet Series 94) New York: Benj. W. Hitchcock, 1870. See also footnote 26 and Abb. 3-5 at the end of this essay. 
powerful national symbol, representing not only a mighty and historically significant German river but also a bulwark against French invasion. Schneckenburger's literary commentary on Germany's oft-contested western border helps explain the renewed popularity in 1870 of his reassuring refrain, "Fest steht und treu die Wacht am Rhein," among Germans living in both Europe and the United States. ${ }^{33}$ As we have seen, both "Die Wacht am Rhein" and Arndt's poem were featured at the "Great Demonstration" in Jones's Wood; according to an article in the New-York Tribune, "Patrol on the Rhine" and "German Fatherland" were also performed at the "Liederkranz Summer's Night Festival" held in the same park one week earlier, on August 12, by members of two rival singing societies, the Liederkranz and the Arion. ${ }^{34}$

This publication presents Reichardt's composition for Arndt's poem; Carl Wilhelm composed the music for Schneckenburger's text. The subtitle on the cover, "Two German National Songs," alludes to German unification and implies that both poems functioned as national anthems for all Germans, regardless of regional differences or loyalties. While Arndt's text takes second billing to "Watch on the Rhine" on the cover (which is decorated with an elaborate border and has no less than eight different typefaces), it is the first song presented. The popular title appears above the musical arrangement, "The German Fatherland"; it is subtitled in German as "Das Deutsche Vaterland" (with the adjective incorrectly capitalized); the German subtitle of each poem is printed in Fraktur. The German verses are provided in italics beneath the English text. While the use of English as the primary language, with German appearing as a translation, suggests that the publication was intended primarily for English speakers within the German-American communities, the sheet music does acknowledge Arndt's original text and the native language of German immigrants.

The first, fifth, and six verses (which correspond to the first, seventh, and tenth stanzas of the original poem) are printed in the musical score, while the second, third, and fourth verses (the second, third, and fourth stanzas of the original poem) are found after the score. Without the sixth and ninth stanzas from Arndt's poem, the text's emphasis shifts from hostilities with other nations, in particular France, to

33 Three thousand Germans living in London performed the song on July 20, 1870, for example, to show their support of the German war effort. See Vanchena: Political Poetry in Periodicals and the Shaping of German National Consciousness in Nineteenth-Century Germany (footnote 6), pp. 46-47, 176-88.

34 "Liederkranz Summer's Night Festival," New-York Tribune, August 13, 1870; see also two articles by Nadel in the Encyclopedia of New York City (footnote 14): "Arion Gesangverein," p. 52, and "Deutscher Liederkranz," p. 329. "Des Deutschen Vaterland" was also being published with "Die Wacht am Rhein" in Germany; Deutschlands Kriegern bei ihrem Durchzuge durch Leipzig im August 1870 (Leipzig: Breitkopf and Härtel, 1870), a small anthology meant for soldiers heading into battle, includes both poems, as does Franz Lipperheide's collection, Lieder zu Schutz und Trutz: Gaben deutscher Dichter aus der Zeit des Krieges in den Jahren 1870 und 1871. Deutschlands Kriegern bei ihrem Durchzuge durch Leipzig im August 1870. Auswahl für Volk und Heer (Berlin: Lipperheide, 1871). 
the establishment of borders for a unified Germany. William Jarvis Wetmore translated Arndt's German somewhat more freely than Sutro did, as seen in the first lines: "What is the German's Fatherland? / Is't Prussia brave, is't Swabia? / Is't on the Rhine, the blooming Rhine,/Or where the Baltic's billows shine?/O no! no! no! / Far greater still is Fatherland!" His fifth verse, moreover, offers a slightly different response to Arndt's main question, one that mentions God only indirectly: "Where is the German's Fatherland? /O where this noble Fatherland? / Tis where the songs of love arise,/In heartfelt accents to the skies./There shall it be, there shall it be,/Brave Germany, that land is thine!" This transformation puts a GermanAmerican spin on Arndt's seventh stanza, for it suggests that Germans singing these lines in the United States not only would be echoing their fellow Germans still living in Europe, they would also be creating a German Fatherland within their American landscape. Two soprano obligatos added to the fifth and sixth verses "Thine! That land is thine!" - further underscore the concept of German unity existing wherever "die deutsche Zunge klingt".

Arndt's poem appears with "Die Wacht am Rhein" in a second piece of GermanAmerican sheet music published in New York City in $1870 .{ }^{35}$ In this case, the original German titles are given on the cover; the English translations appear beneath them, in much smaller type and in parentheses: "Where is the German Fatherland" and "The Guard on the Rhine." As indicated on the cover, the music has been arranged "Für Piano (Mit und ohne Gesang)." F. Lüdke arranged both songs, using Reichardt's and Wilhelm's compositions. Another note on the front cover states that proceeds from the sale of this music would be sent to the "hülfsbedürftigen Familien deutscher Krieger”, recalling the fundraising event at Jones's Wood. The cover illustration depicts two banners that resemble the black-red-gold German flag; the banners and their staffs, which are entwined in an elaborate latticework, thus form a pictorial allusion to German unification. Given the presentation and clearly stated purpose of this musical arrangement, German-speaking immigrants were expected to be the primary customers, although the translation of the poems' titles might have ensured that English-speaking German-Americans also would have been encouraged to support this charitable endeavor. At the very least, the English translations of the poems' titles signify recognition of the predominant language in the United States. This publication presents the same verses found in the sheet music discussed above (the first four and the seventh and tenth stanzas of Arndt's original poem), although here they are printed in the original sequence. Given the absence of the sixth and ninth stanzas in particular, emphasis lies once again on German unification rather than on the war against France or other previous conflicts.

A third publication that attests to the adaptation of Arndt's poem in the United States is also in the form of sheet music; printed in Philadelphia in 1870 by Louis Meyer ("Publisher and Dealer in American \& Foreign Music"), it features only

35 Was ist des Deutschen Vaterland und Die Wacht am Rhein. Arranged by F. Lüdke. New York: Lüdke 1870. See Abb. 6 at the end of this essay. 
Arndt's poem. ${ }^{36}$ Although the cover is primarily in English, the original German title of Arndt's poem appears in the largest and boldest font; it follows an English translation: "The German Fatherland. Was ist des Deutschen Vaterland?" The poem is characterized as an anthem, a "German National Song For Singing and Piano Solo" (the piano accompaniment serves as a piano solo arrangement); the melody, once again Reichardt's, is to be sung "mit Feuer." On the first page of the publication, the German title again follows the English translation (The German Fatherland. Was ist Des Deutschen Vaterland). The German verses are printed in the traditional location, however (between the melody provided for singers on a single staff and the piano accompaniment), which lends them importance; the translated verses appear above the melody line. The same six verses are included in this publication (stanzas one through four, seven, and ten); stylistically, this anonymous English translation resembles Sutro's version more than it does Wetmore's: "Where is the German's fatherland? / Is't Swabia? Is't the Prussian's land?/Is't where the grape glows on the Rhine?/Where seagulls skim the Baltic's brine?/O no! more grand/ Must be the German's fatherland!" Arndt's important seventh stanza is rendered as follows: "Where is the German's fatherland?/Name me at length that mighty land!/Where'er resonds the German tongue,/Where'er its hymns to God are sung. / Be this the land, be this the land,/ Brave German, this thy fatherland!"

Arndt's patriotic verses can also be found in nineteenth-century German-American poetry anthologies. One particularly interesting volume from 1883, Germania Heimathsklänge: Deutsch-English Illustrirtes Volksliederbuch für die Deutschen Amerika's contains "Des Deutschen Vaterland" and several additional patriotic poems from the first half of the nineteenth century, including "Die Wacht am Rhein", Hoffmann von Fallersleben's "Das Deutschlandlied", and Theodor Körner's "Lützows wilde Jagd". 37 "Des Deutschen Vaterland" comprises seven stanzas instead of the usual six (the first through the fifth, the seventh, and the tenth stanzas of the original poem); once again, however, all mention of the French and other foreign foes has been excluded.

Published by Georg Brumder in Milwaukee, Wisconsin (another city with a significant German population), the volume's preface underscores a fact reflected in the book's title. ${ }^{38}$ Brumder explains that the intended readership for this volume was the German-American community:

36 The German Fatherland. Was ist des Deutschen Vaterland? German National Song For Singing and Piano Solo. Philadelphia: Louis Meyer 1870. See Abb.7-10 at the end of this essay. Philadelphia, like New York City, was home to a large German immigrant population; the first German families to arrive in the United States, Mennonites from the Rhine valley, settled in the city in 1683. German publishing also flourished there; the first American German-language newspaper, the Philadelphische Zeitung, was founded in the city in 1732.

37 Georg Brumder (ed.): Germania Heimathsklänge: Deutsch-English Illustrirtes Volksliederbuch für die Deutschen Amerika's. Milwaukee: Brumder 1883. "Lützows wilde Jagd" (1813), by Theodor Körner (1791-1815), was one of the most popular patriotic songs written during the Wars of Liberation.

38 The number of German-born persons living in Wisconsin peaked in 1890 at nearly 260,000 . Known as the "German Athens", Milwaukee boasted many German-American cultural 
Unsere Absicht bei der Herausgabe dieses Liederbuches geht dahin aus dem üppigen Blumenflor deutscher Volkslieder einen vollen Strauß zu pflücken, der des Aufhebens auch in dieser unserer neuen Heimath werth ist. [... Wer es durchblättert von Denen, die der Jugend goldene Tage in Deutschland gesehen, dem wird es die Erinnerung wachrufen an das Vaterland, wer von dem hiergeborenen Nachwuchs, dem wird es das Verständnis erleichtern für deutsches Wesen, welches sich fast nirgends so unmittelbar kundgibt wie im deutschen Liede. ${ }^{39}$

While he romanticizes the childhood experiences of German immigrants, he also accepts America as his and their new home. He acknowledges the acculturation process, but preserving an appreciation of poetry among those of German descent is not his only concern: he expects some readers to question whether "die spezifisch deutsch-patriotischen Lieder" should be included in a book published not for Germans but for German-Americans. He concludes the preface with an additional reason for embracing patriotic poems. Drawing on traditional nature metaphors often found in nineteenth-century German poetry, he emphasizes the role poetry had played in the construction of a German national identity long before a unified country existed:

Wir konnten aber auch aus anderem Grunde jene Weisen nicht fortlassen; ohne sie, die unsere Väter und Brüder und ein Theil von uns selber gesungen haben bei Kampf und Sieg. würde unsere Sammlung sein wie ein Wald, der nicht rauscht, und ein Meer, das nicht brandet. $^{+0}$

Brumder decided in the end to include such poems because he believed that the majority of people purchasing the book would want to find them between its covers.

To appease those in the minority, however, Brumder included American poems in his anthology; entitled Home Songster: A Collection of the Most Patriotic and Popular Songs and Marching Choruses, this separate volume was appended inside the back cover of the first volume. The collection includes a broad and diverse selection of patriotic texts: "America" (My Country, 'tis of thee, Sweet land of Liberty), the first poem in the anthology;"Home, Sweet Home";"Yankee Doodle"; and the "Star Spangled Banner".41 No authors' names are given in this beautifully illustrated volume, reflecting the title's claim that the poems were indeed popular and wellknown folksongs. Brumder's collection, which combines in one publication examples of both the German and the American poetic traditions, represents a German-American's attempt not only to preserve German cultural identity but also to help create a hybrid identity, one that was necessarily shaped by the American landscape.

societies and institutions. See Richard H. Zeitlin: Germans in Wisconsin, revised and expanded edition. Madison: The State Historical Society of Wisconsin, 2000.

39 Brumder (ed.): Germania Heimathsklänge (footnote 37). pp. 192-93.

40 Ibid., pp. iii-iv.

41 "America" was written in 1831 by Samuel Francis Smith (1808-95). "Home. Sweet Home" was originally an aria in Clari, or The Maid of Milan ("Sicilian Air"), composed by Henry Bishop (1786-1855) in 1821; John Howard Payne (1791 - 1852) wrote the libretto. "Yankee Doodle" became popular during the American Revolution; it was first used by British troops to mock revolutionaries, but Americans adopted the song in the late eighteenth century. 
Although Arndt wrote several patriotic poems that remained popular in the German states throughout the nineteenth century and well into the twentieth century, the evidence presented in this essay suggests that "Des Deutschen Vaterland" was the poem most frequently published and performed by German-Americans in the 1870 s and early 1880 s. This evidence should not be considered exhaustive; given the large number of German-American communities and German-language periodicals and publishing houses in the United States in the latter part of the nineteenth century, one could expect to find additional publications featuring "Des Deutschen Vaterland" as well as further accounts of festivals and programs at which the poem was performed. The twentieth century would also yield evidence; Arndt's "Bundeslied" (1815), to give just one example, appears as "Union Song" in $A$ Harvest of German Verse, an English-language anthology published in $1916.42 \mathrm{~A}$ perusal of approximately thirty nineteenth-century German-American poetry anthologies (published in English and German) did not yield examples of poets who had borrowed or imitated Arndt's "Des Deutschen Vaterland", or any of his other well-known patriotic poems, to comment on American social, political, or cultural exigencies. This observation suggests that the relationship of German-American poets to this established German literary tradition was influenced, at least to some degree, by the process of acculturation - by their geographical and emotional distance to the German fatherland, and by circumstances prevalent in the American landscape. ${ }^{43}$ As we have seen, however, German-Americans did take up Arndt's "Des Deutschen Vaterland", often adapting the poem to their new national context while at the same time using it to maintain and demonstrate their ties with Germans living across the Atlantic. In doing so, they accorded the poem a role in shaping their intracultural identity and contributed to the multi-ethnic character of the United States.

42 A Harvest of German Verse, selected and translated by Margarete Münsterberg. New York: D. Appleton and Company 1916, p. 85. Published during World War I, the poem would have resonated among German-Americans who supported their fellow countrymen fighting in Europe: "This blessed hour we are united,/Of German men a mighty choir,/ And from the lips of each, delighted,/Our praying souls to heaven aspire; / With high and sacred awe abounding, / We join in solemn thoughts to-day, / And so our hearts should be resounding/In clear harmonic song and play." For the original German text, see Ernst Moritz Arndt: Gedichte II, edited by Heinrich Meisner. In: Arndts ausgewăhlte Werke in sechzehn Bänden (footnote 3), vol. 3, pp. 100-01.

43 An investigation of whether or not Arndt's poetry influenced nineteenth-century American poetry may provide additional insight on the adaptation of his German cultural material. I thank Thomas Stamm-Kuhlmann for a thought-provoking discussion about the Americanization of Arndt's poetry during the international Arndt symposium held in Lawrence, Kansas in September 2005. 


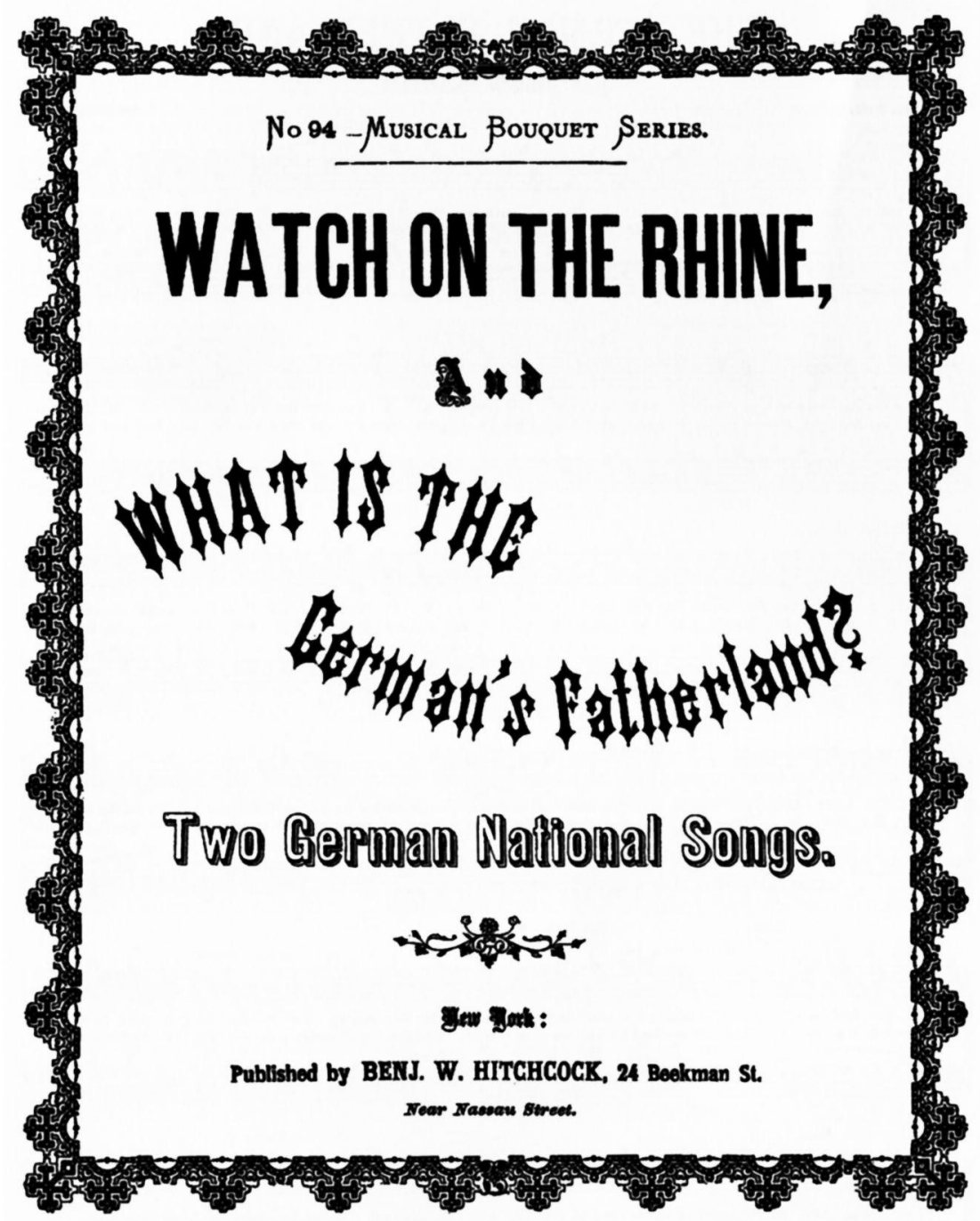

Abb. 3: (Abb. 3-5) Watch on the Rhine and What is the German's Fatherland?: Two German National Songs. (Musical Bouquet Series 94) New York: Benj. W. Hitchcock, 1870. (footnote 32). Source: Sheet music collection at Dartmouth College, Hanover, N. H. 


\section{THE GERMAN FATHERLAND.}

Dagllah Words by Dr. W. J. WETtione.

Das Deutfape Fofertanb.

c. recoerer.

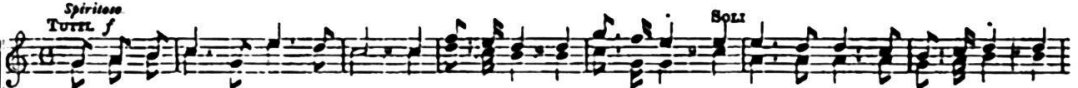

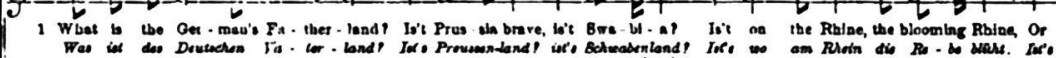

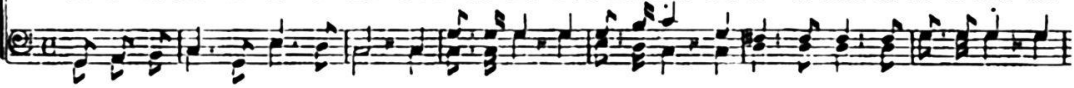

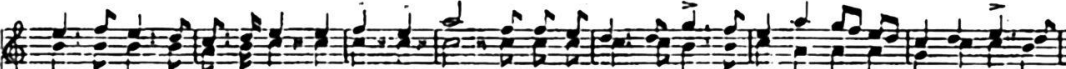

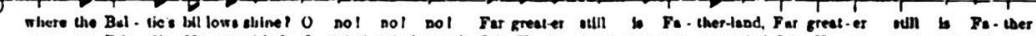

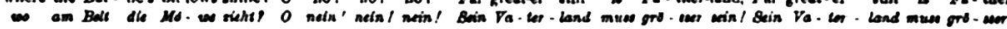

팔

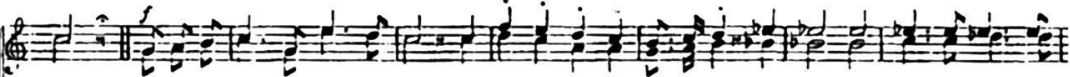

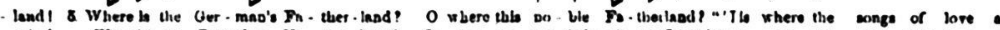

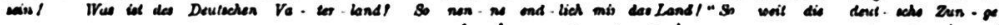

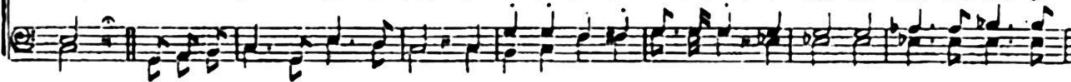

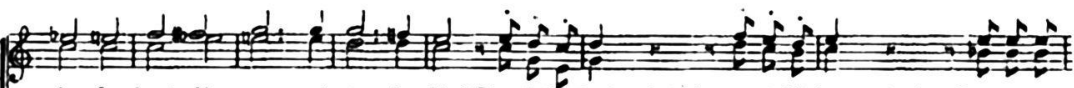

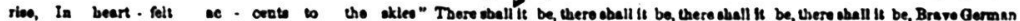

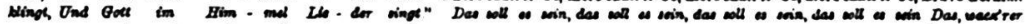
P. thlop!

that land to thlan!
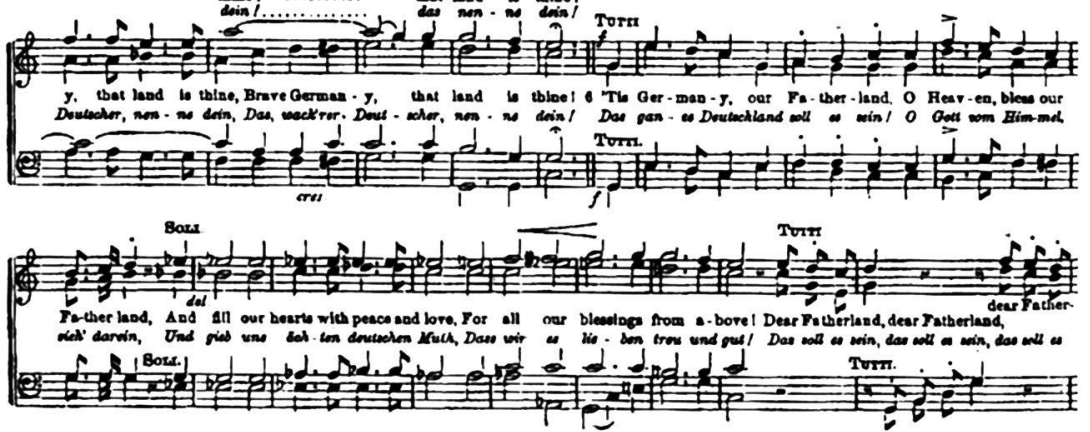

Abb. 4 


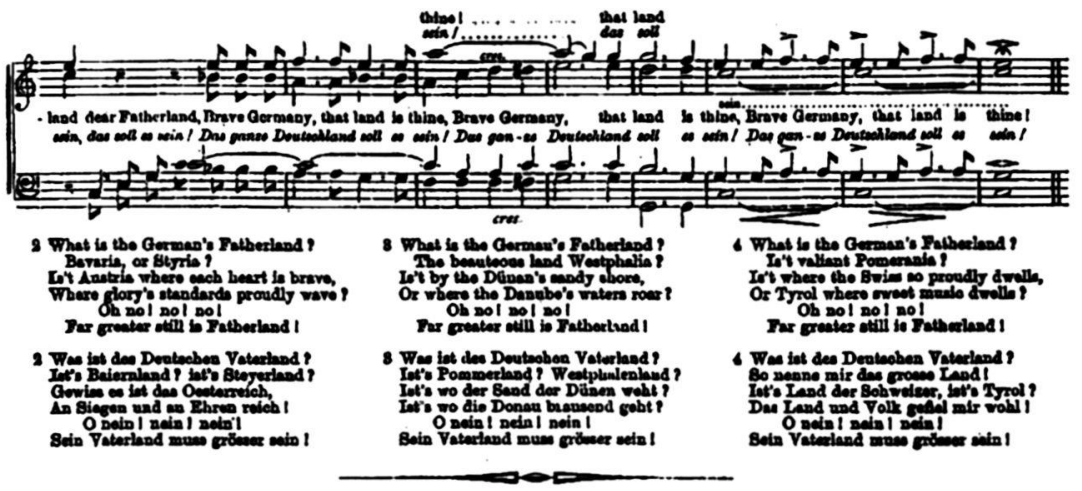

\section{THE WATCH ON THE RHINE. Die sacpt an socin.}
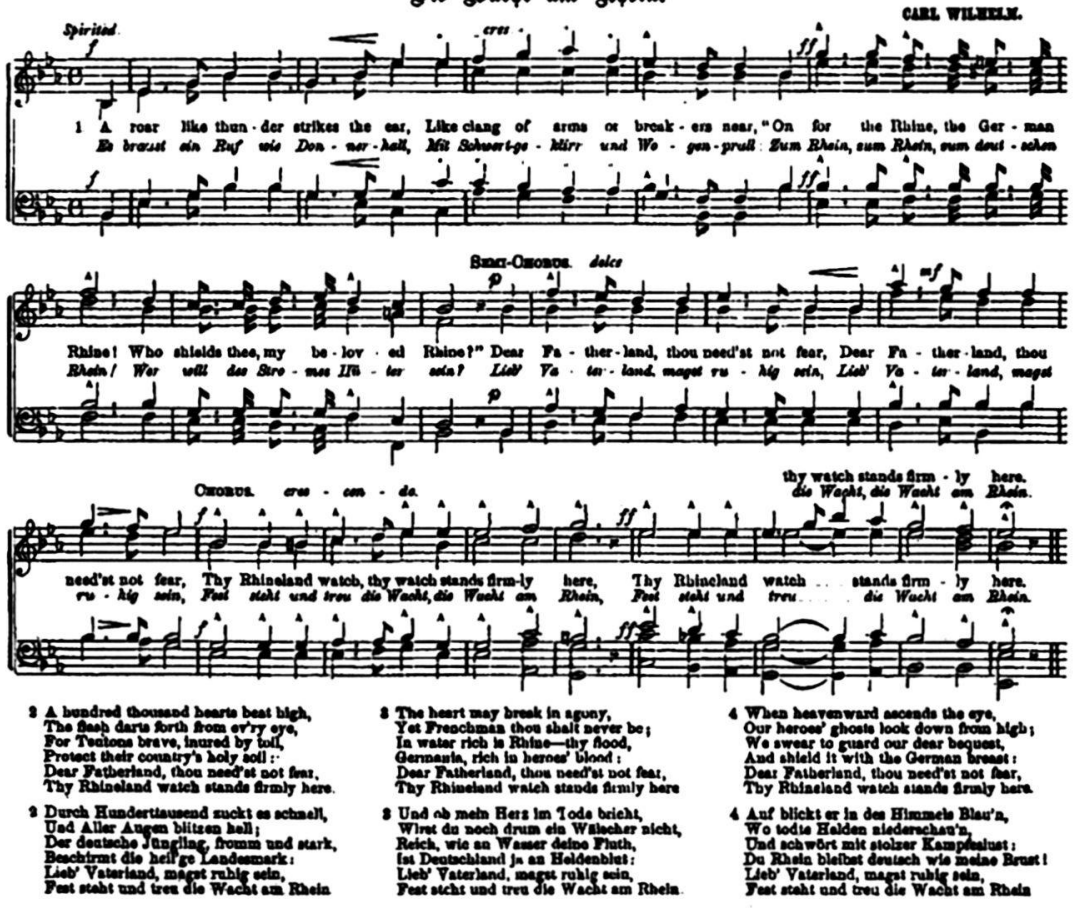

Abb. 5 


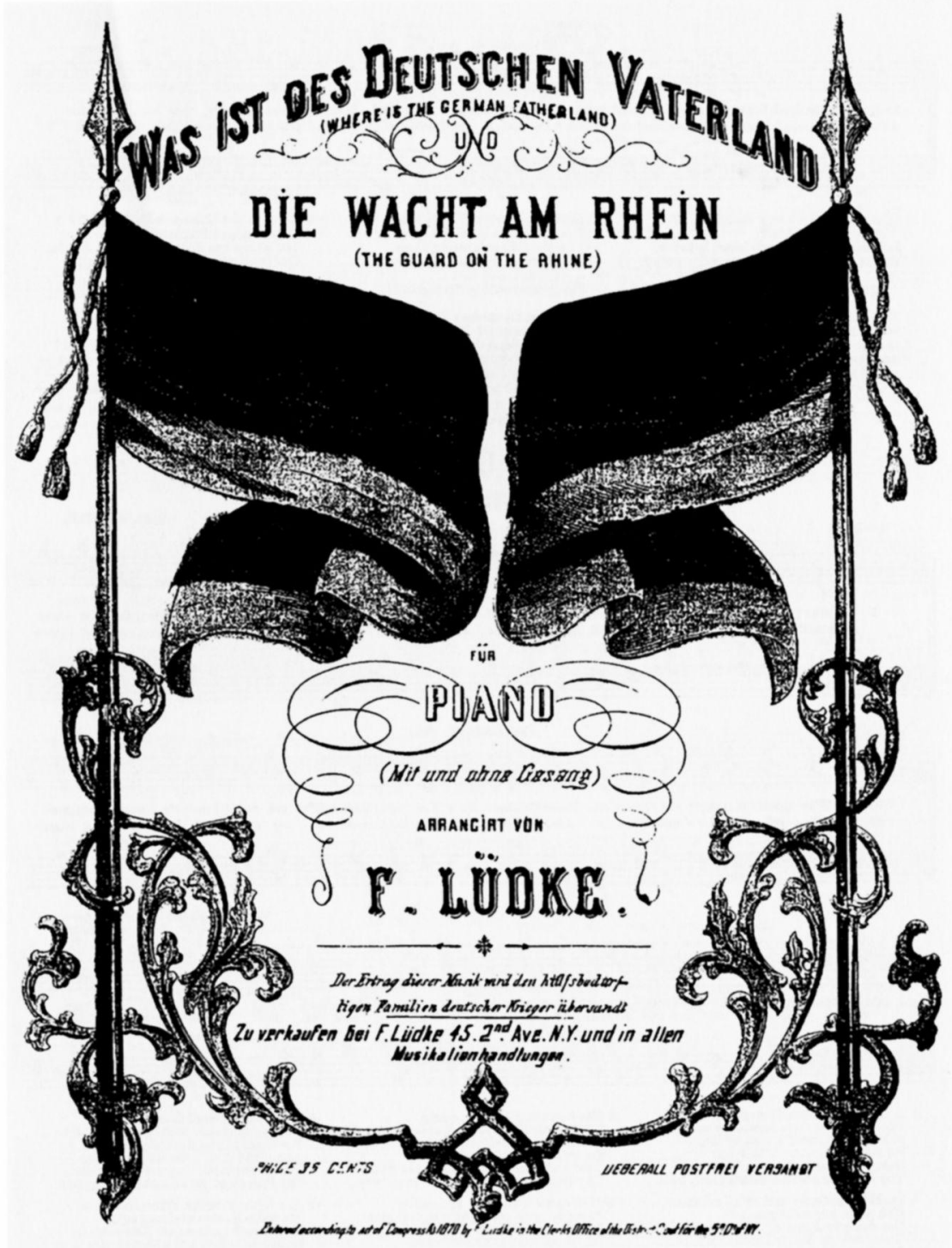

Abb. 6: Was ist des Deutschen Vaterland und Die Wacht am Rhein. Arranged by F. Lüdke. New York: Lüdke 1870 (footnote 35). Source: Sheet music collection at Dartmouth College, Hanover, N. H. 

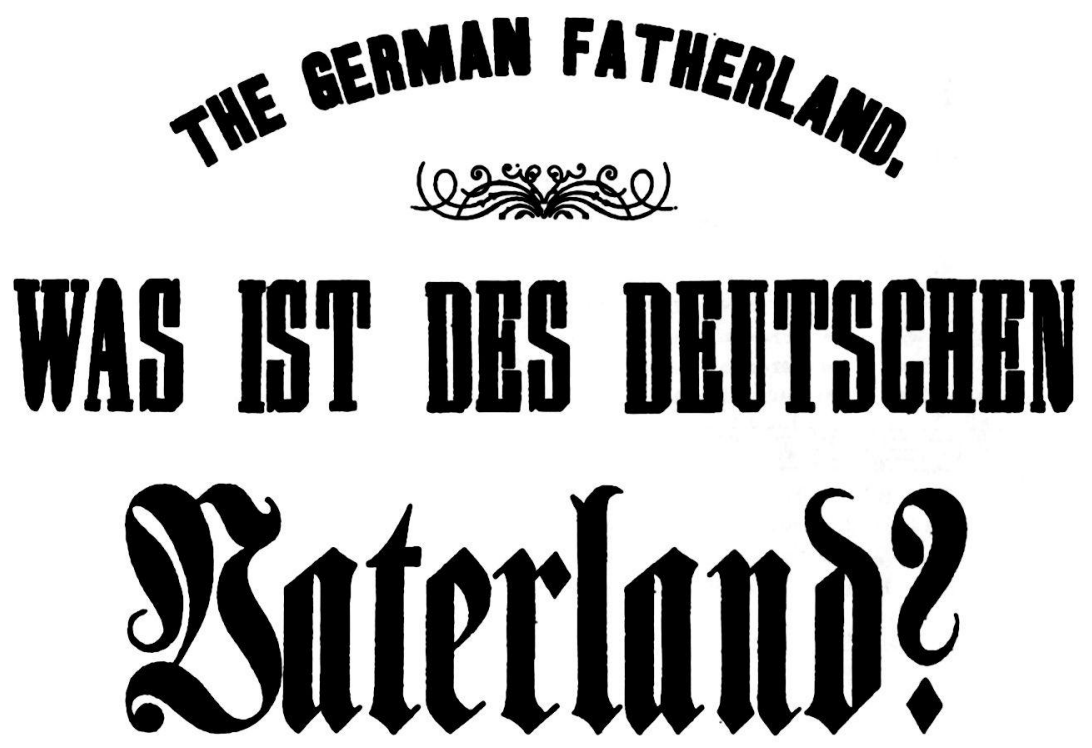

GMRPAN MATOMAL SONG

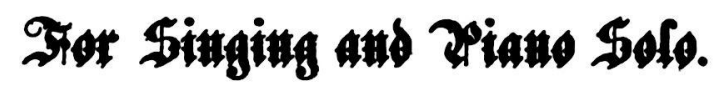

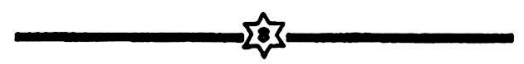

PEIILADERTEIA:

LOUIS MEYER, 1413 CHESTNUT STREET.

Abb. 7: (Abb.7-10) The German Fatherland. Was ist des Deutschen Vaterland? German National Song For Singing and Piano Solo. Philadelphia: Louis Meyer 1870. (footnote 36). Source: Sheet music collection at Dartmouth College, Hanover, N. H. 


\section{THE GERMAN FATHERLAND.}

\section{WAS IST DES DEUTSCHEN VATERLAND}

A N NT

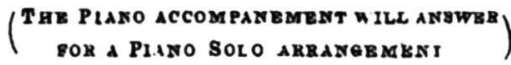

\section{G REICHARDT}

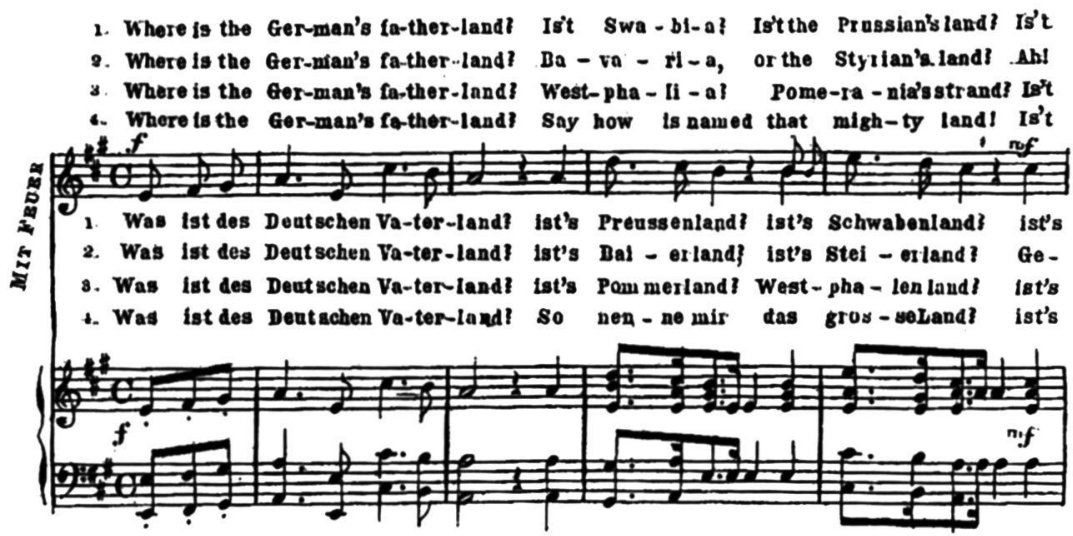

1. where the grape gluws on the Rhinel Where sea-gulls sicim the Baltiog brine? 0 no! more

2. Austria sure-ly it must be, In hon-ours rich and vic-to-ry, mol more

9. where the sand warts on the shore? It's where the Danubes surgesroar? 0 no! more

4. Ty-rol! where the Switzers dwell? The land and peo-ple pleasemewell 0 no! more

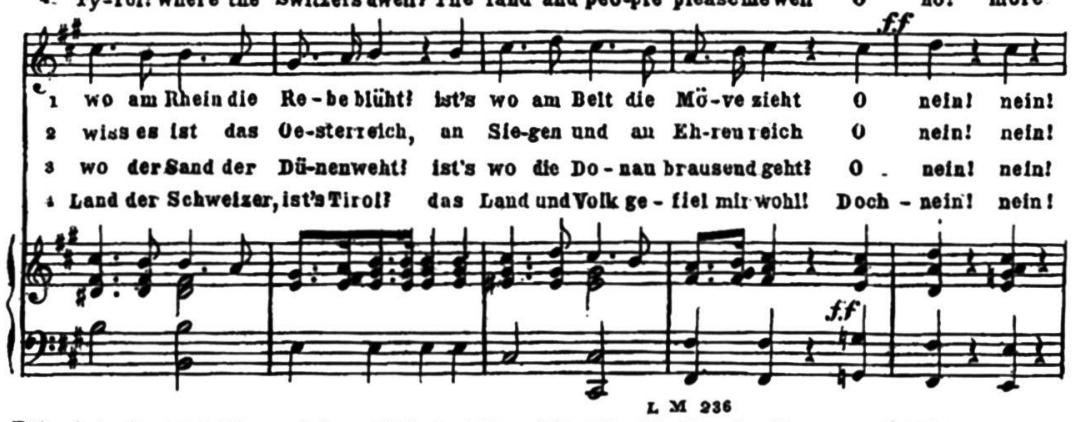

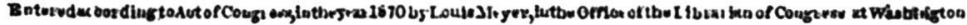

Abb. 8 
grand Must be the Guman's fa-ther-land! Inst be the German's lather-land Where is the

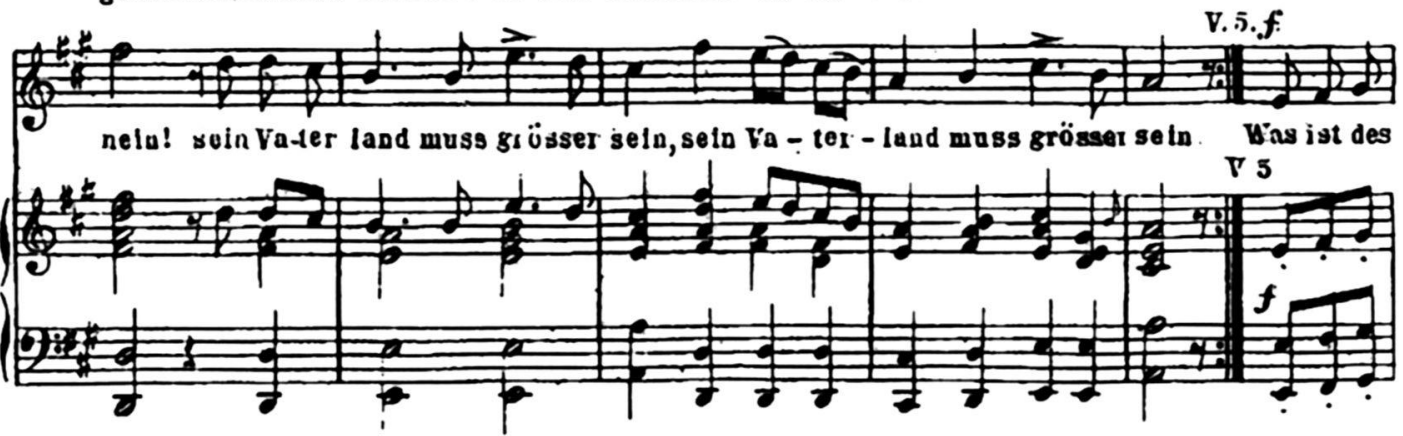

German's father-land ! Nama mo at length that mighty land! Wheie'-er ro-sounds the Gerwan
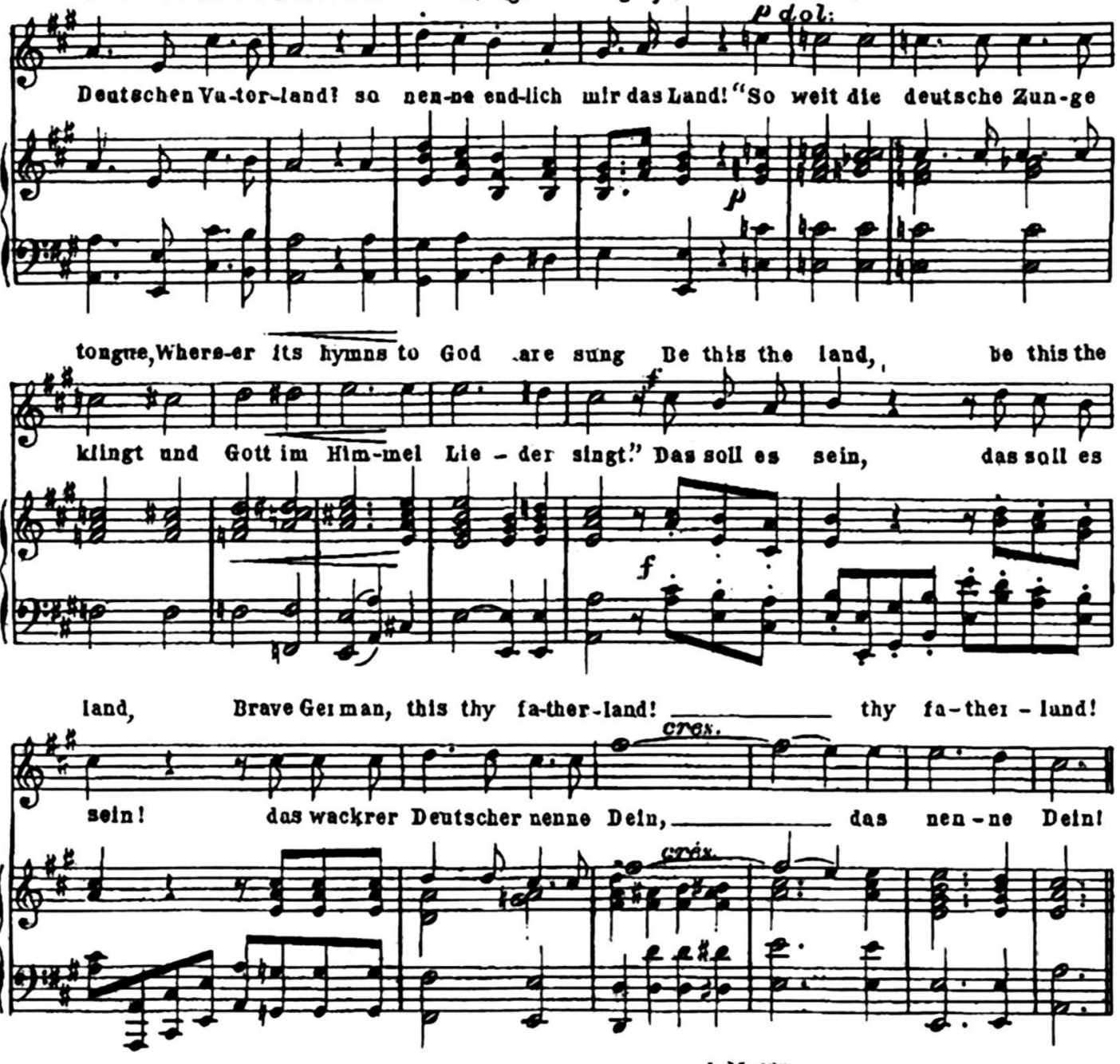

Abb. 9 
$f$

V 6 All Ger-ma-ny that land shall be, watch o'er it God, and grantthatwe, with

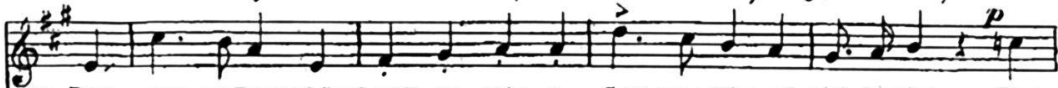
V6 Das gan-ze Deatschland soll es sein, o Gott vom Himmel sieh darein! Und

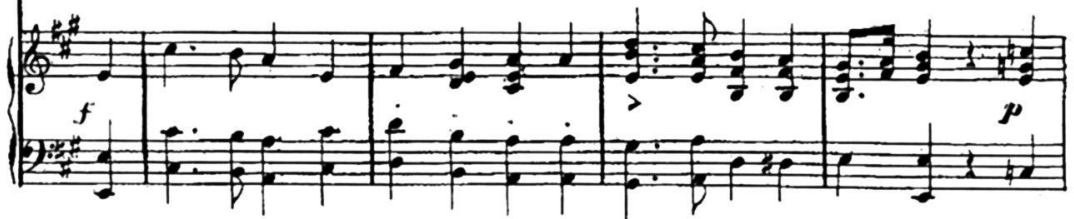

Ger-man hearts, in deed and thought, May love it tru-ly as we
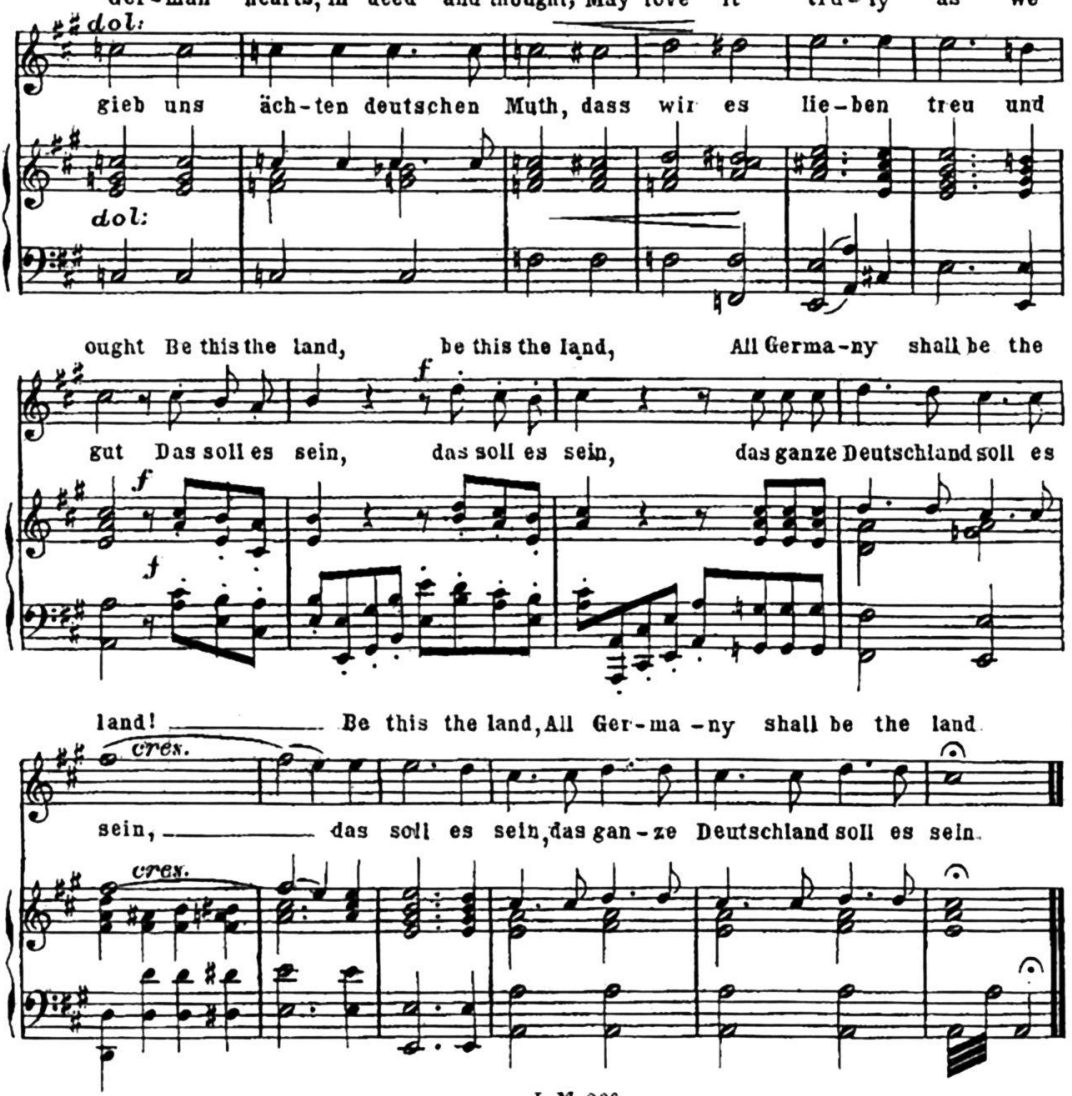

L M 236

Abb. 10 